\title{
PENGARUH VARIASI LAPIS GEOSINTETIK TERHADAP SAFETY FACTOR TIMBUNAN DI ATAS TANAH LUNAK
}

\author{
Bambang Setiawan ${ }^{1}$, R Harya Dananjaya ${ }^{1}$, Fitria Anggraeni ${ }^{2}$ \\ ${ }^{1}$ Staf Pengajar Program Studi Teknik Sipil, Universitas Sebelas Maret Surakarta. \\ ${ }^{2}$ Mahasiswa Program Studi Teknik Sipil, Universitas Sebelas Maret Surakarta. \\ Jl. Ir. Sutami No. 36A, Jebres, Surakarta 57126; Telp. 0271-634524 \\ Email : tiaanggra16@gmail.com
}

\begin{abstract}
Soft soil is the type of soil that is often found in Indonesia. The building is not safe to be built on soft soil. This is because soft soil has a low CBR and N-SPT value, low shear strength, high water content, and a high risk of settlement. The aim of this study is to determine the effect geosynthetic layer's variations for safety factor, settlement, and stress in soft soil. This study use variations in geosynthetic types, the number of geosynthetic layers, and the spaces between layers of geosynthetic. This study is a quantitative research by means of secondary data collection and modeling data with finite element method (FEM). The result of this study indicates that the used of optimum geosynthetic layer's variations can increase safety factor by $23,79 \%$, decrease settlement by 2,60\%, and increase stress soil by 0,17\%.
\end{abstract}

Keywords: embankment, geosynthetic, safety factor.

\begin{abstract}
Abstrak
Tanah lunak merupakan jenis tanah yang sering dijumpai di Indonesia. Tanah lunak merupakan jenis tanah yang tidak aman untuk didirikan konstruksi di atasnya. Hal tersebut terjadi dikarenakan beberapa sifat tanah lunak yaitu memiliki nilai $C B R$ dan N-SPT yang rendah, gaya geser yang rendah, kadar air tinggi, koefisien permeabilitas yang rendah, daya dukung yang rendah, dan resiko adanya settlement atau penurunan yang besar. Tujuan dari penelitian ini adalah untuk mengetahui pengaruh variasi lapis geosintetik terhadap perubahan nilai safety factor, settlement, dan tegangan tanah pada tanah lunak. Variasi yang digunakan pada penelitian ini adalah variasi jenis geosintetik, jumlah lapis geosintetik, dan jarak antar lapis geosintetik. Penelitian ini merupakan penelitian kuantitaif melalui pengumpulan data sekunder serta pemodelan dengan analisis metode elemen hingga $(\mathrm{MEH})$. Hasil penelitian menunjukkan bahwa variasi lapis geosintetik paling optimum dapat meningkatkan nilai safety factor sebesar 23,79\%, menurunkan nilai settlement sebesar 2,60\%, dan meningkatkan tegangan tanah sebesar 0,17\%.
\end{abstract}

Kata Kunci : tanah timbunan, geosintetik, safety factor.

\section{PENDAHULUAN}

Tanah lunak merupakan jenis tanah yang sering dijumpai di Indonesia (Pedoman Kimpraswil No: Pt T-10-2002B). Tanah lunak merupakan jenis tanah yang tidak aman untuk didirikan konstruksi diatasnya. Hal tersebut terjadi dikarenakan beberapa sifat tanah lunak yaitu memiliki nilai CBR dan N-SPT yang rendah, gaya geser yang rendah, kadar air tinggi, koefisien permeabilitas yang rendah, daya dukung yang rendah, dan resiko adanya settlement atau penurunan yang besar.

Geosintetik merupakan salah satu perkuatan yang mampu mengurangi sifat merugikan yang dimiliki oleh tanah lunak, yaitu menaikan safety factor dan memperkecil settlement. Pemasangan geosintetik sebagai perkuatan tanah lunak akan memberi hasil yang berbeda-beda bergantung pada desain serta variasi pemasangan jenis geosintetik yang digunakan.

Penelitian terdahulu tentang pengaruh jumlah lapisan dan spasi perkuatan geosintetik terhadap kuat dukung dan penurunan tanah lempung lunak telah dilakukan oleh Anita (2012) dengan pemodelan menggunakan kotak model tanah dasar yang dilengkapi dengan rangka untuk uji pembebanan. Penelitian tersebut menunjukkan hasil yang signifikan mengenai peningkatan kekuatan tanah yang sebanding dengan penambahan jumlah lapis geosintetik, pengurangan tingkat penurunan tanah yang sebanding dengan penambahan jumlah geosintetik, serta penurunan kekuatan tanah yang sebanding dengan penambahan spasi lapis geosintetik.

\section{Perkuatan Geosintetik pada Timbunan di Atas Tanah Lunak}

Fungsi geosintetik sebagai perkuatan pada konstruksi timbunan (geosynthetic design and construction guidelines, 1995) adalah meningkatkan faktor keamanan, menambah tinggi timbunan, mencegah pergeseran timbunan selama pelaksanaan, baik pergeseran vertikal maupun horizontal, dan memperbaiki kinerja timbunan karena penurunan pasca konstruksi yang seragam. 
Faktor keamanan global timbunan dengan perkuatan geosintetik menurut Bringgreve (2012) dapat dihitung dengan persamaan [1] berikut ini,

$$
S F=\frac{c-\sigma_{n} \tan \varphi}{c_{r}-\sigma_{n} \tan \varphi_{r}}
$$

$S F$ adalah faktor keamanan global pemodelan; $c$ adalah kohesi tanah; $c_{r}$ adalah kohesi reduksi; $\varphi$ adalah sudut geser tanah; $\varphi_{r}$ adalah sudut geser reduksi.

\section{Konsolidasi dan Settlement}

Konsolidasi adalah tingkat perubahan volume dalam suatu proses pemadatan, dan histori dari proses ini biasanya diberikan oleh diagram hubungan waktu-pemadatan, yang ditandai dengan tiga zona kompresi yaitu initial compression zone, primary consolidation zone, secondary consolidation zone. Settlement atau penurunan merupakan nilai reduksi dari ketebalan lapisan tanah akibat suatu proses pemadatan yang dialami oleh lapisan tanah tersebut.

Nilai settlement menurut Bowles (1997) dapat dihitung dengan Persamaan [2] berikut ini,

$$
S=H \frac{c_{c}}{1+e_{0}} \log \frac{p_{0+\Delta p}}{p_{0}}
$$

$S$ adalah settlement; $H$ adalah ketebalan lapisan tanah; $C c$ adalah koefisien kompresi tanah; $e_{0}$ adalah void ratio; $p_{0}$ adalah tekanan awal; $\Delta p$ adalah perubahan tekanan.

\section{Tegangan Tanah}

Tegangan tekan $(\sigma)$ yang bekerja pada massa tanah sebagian akan ditanggung oleh partikel tanah dan sebagian lagi oleh tekanan air pori. Gabungan dari keduanya disebut dengan tegangan total, sedangkan tegangan yang ditanggung oleh partikel tanah disebut tegangan efektif $\left(\sigma^{\prime}\right)$. Secara umum menurut Terzaghi (1923) tegangan efektif dihitung melalui persamaan [3] berikut ini,

$$
\sigma^{\prime}=\sigma-u
$$

$\sigma^{\prime}$ adalah tegangan tanah efektif; $\sigma$ adalah tegangan tanah total; $u$ adalah tekanan air pori.

\section{Metode Elemen Hingga}

Metode elemen hingga merupakan suatu metode penyelesaian numerik dengan cara membagi kontinum menjadi bagian-bagian yang lebih kecil. Konsep dasar metode elemen hingga adalah apabila suatu sistem dikenai gaya luar, maka gaya luar tersebut diserap oleh sistem tersebut dan akan menimbulkan gaya dalam dan perpindahan. Gaya dalam dan perpindahan akibat gaya luar tersebut dapat diketahui dengan membentuk suatu persamaan yang mewakili sistem tersebut. Keseluruhan sistem dalam metode elemen hingga dibagi kedalam elemen elemen dengan jumlah tertentu.

\section{METODE}

Penelitian ini merupakan penelitian kuantitaif melalui pengumpulan data sekunder serta pemodelan dengan analisis elemen hingga untuk mengetahui hasil penelitian yang meliputi nilai daya dukung tanah, settlement, dan tegangan tanah. Data tanah yang digunakan dalam penelitian ini merupakan data tanah sekunder yang didapat dari data tanah lunak di Sidoarjo. Data geotextile dan geogrid yang digunakan merupakan data sekunder yang didapat dari PT. Tetrasa GEOSININDO. Data-data tersebut ditampilkan pada Tabel 1 sampai dengan Tabel 3 berikut ini,

Tabel 1. Data tanah eksisting

\begin{tabular}{llllllllll}
\hline \multicolumn{2}{c}{$\gamma\left(\mathbf{k N} / \mathbf{m}^{3}\right)$} & $\begin{array}{l}\mathbf{E 5 0} \text { ref } \\
\left(\mathbf{k N} / \mathbf{m}^{2}\right)\end{array}$ & $\begin{array}{l}\boldsymbol{c} \\
\left(\mathbf{k N} / \mathbf{m}^{2}\right)\end{array}$ & $\boldsymbol{\phi}\left(^{\circ}\right)$ & $\mathbf{k x}$ & $\mathbf{k y}$ & $\mathbf{v}$ & $\boldsymbol{\psi}$ \\
\hline $\begin{array}{l}\gamma \\
\text { (unsat) }\end{array}$ & $\gamma(\mathbf{s a t})$ & & & & & & \\
\hline 16,083 & 16,085 & 3922,660 & 11,768 & 4,000 & 0,042 & 0,042 & 0,400 & 0,000 \\
\hline
\end{tabular}

Tabel 2. Data tanah timbunan

$\begin{array}{lllllll}\gamma\left(\mathrm{kN} / \mathrm{m}^{3}\right) & \phi\left(^{\circ}\right) & \mathrm{kx} & \mathrm{ky} & \mathrm{v} & \psi\end{array}$




\begin{tabular}{lllllllll}
\hline $\begin{array}{l}\gamma \\
\text { (unsat) }\end{array}$ & $\gamma$ (sat) & $\begin{array}{l}\mathbf{E 5 0} \text { ref } \\
\left(\mathbf{k N} / \mathbf{m}^{2}\right)\end{array}$ & $\begin{array}{l}\boldsymbol{c} \\
\left(\mathbf{k N} / \mathbf{m}^{2}\right)\end{array}$ & & & & & \\
\hline 12,062 & 17,249 & 73550,000 & 3,923 & 28,000 & 0,007 & 0,007 & 0,300 & 0,000 \\
\hline
\end{tabular}

Tabel 3. Data material geosintetik

\begin{tabular}{lll} 
Tipe & $\mathbf{N p}\left(\mathbf{k N} / \mathbf{m}^{2}\right)$ & $\mathbf{E A}\left(\mathbf{k N} / \mathbf{m}^{2}\right)$ \\
\hline Geotextile GRX50 & - & 142,857 \\
\hline Geogrid GX(40/40) & 23,700 & 260,000 \\
\hline
\end{tabular}

Variabel penelitian dalam penelitian ini adalah jumlah lapis geosintetik $(0 ; 1 ; 2 ; 3 ; 4)$, jarak antar lapis (100mm; 200mm; 300mm; 400mm; 500mm), jenis geosintetik (geotextile dan geogrid). Geometri model penelitian ditampilkan pada Gambar 1 berikut ini,
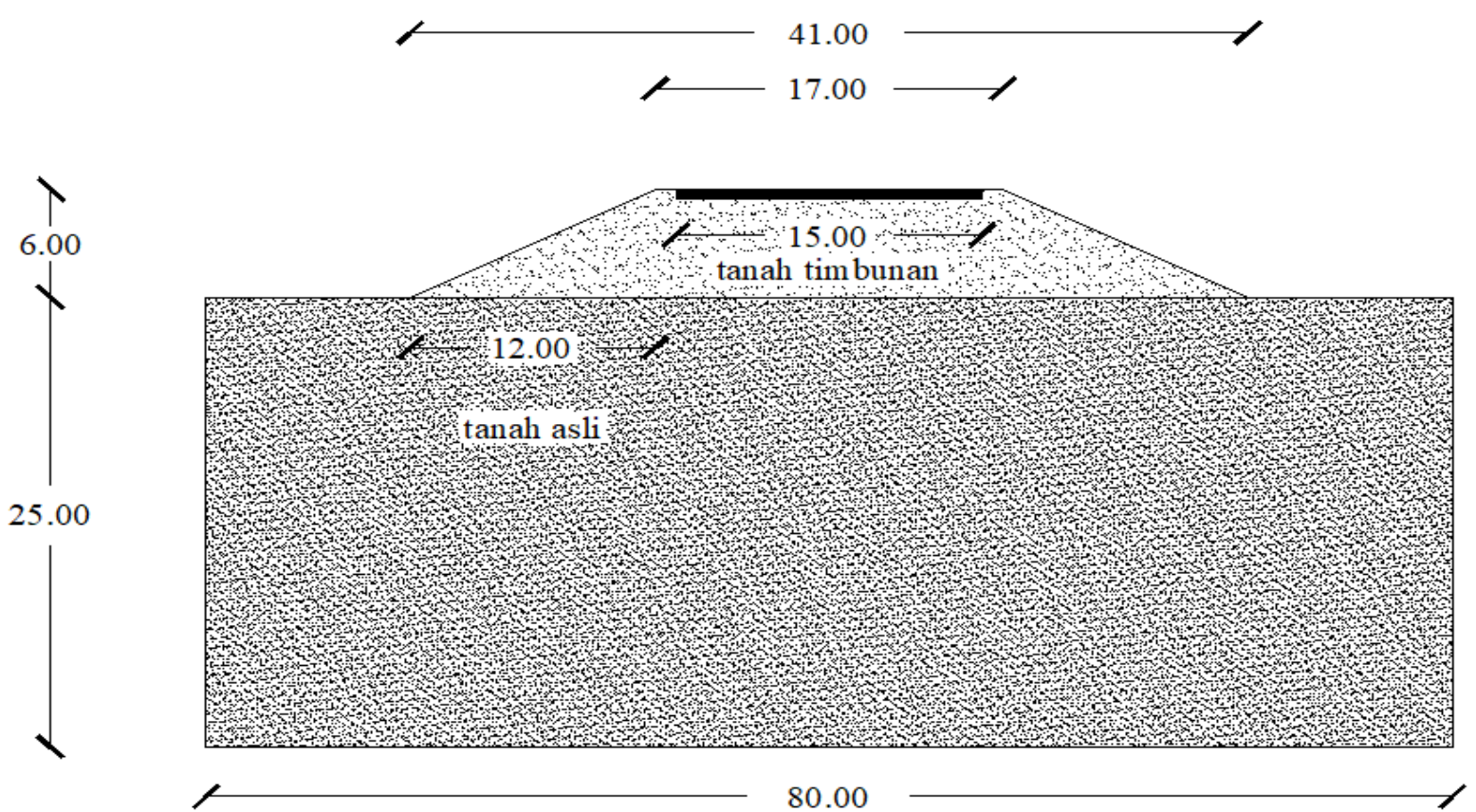

Gambar 1. Geometri penelitian

Gambar 1 menunjukkan geometri pemodelan dengan tinjauan panjang tanah eksisting sepanjang $80 \mathrm{~m}$ dari titik 0 yang berada pada pojok kiri bawah gambar, sedangkan kedalaman tanah eksisting yang ditinjau adalah 25.m. Timbunan dengan ketinggian $3 \mathrm{~m}$, lebar atas timbunan $17 \mathrm{~m}$, lebar bawah timbunan $41 \mathrm{~m}$, serta kemiringan 1:4 yang diasumsikan bahwa kemiringan tersebut sudah memenuhi syarat aman timbunan. Panjang total perkerasan jalan pada pemodelan adalah $15 \mathrm{~m}$ dengan bahu jalan dua kali $1 \mathrm{~m}$. Beban vertikal pada pemodelan yaitu sebesar $60 \mathrm{kN}$ dengan arah menuju pusat grafitasi bumi.

\section{HASIL DAN PEMBAHASAN}

Hasil analisis metode elemen hingga yang telah dilakukan mengindikasikan bahwa variasi lapis geosintetik mampu meningkatkan nilai safety factor, memperkecil nilai settlement, dan meningkatkan nilai tekanan tanah. Hasil analisis ditampilkan dalam Tabel 4 berikut ini,

Tabel 4. Hasil analisi metode elemen hingga

\begin{tabular}{lllll}
\hline No & Notasi & Safety factor & Settlement $\mathbf{( m m )}$ & Tegangan tanah $\mathbf{( k N / \mathbf { m } ^ { 2 } )}$ \\
\hline 1 & 0 lapis & 1,3946 & $-305,29$ & $-289,32$ \\
\hline 2 & Gd-1 & 1,5201 & -303.68 & $-289,40$ \\
\hline
\end{tabular}




\begin{tabular}{|c|c|c|c|c|}
\hline 3 & Gd-2-100 & 1,6207 & $-300,09$ & $-289,57$ \\
\hline 4 & Gd-2-200 & 1,6189 & -300.09 & $-289,57$ \\
\hline 5 & Gd-2-300 & 1,6178 & $-300,72$ & $-289,58$ \\
\hline 6 & Gd-2-400 & 1,6161 & $-300,78$ & $-289,58$ \\
\hline 7 & Gd-2-500 & 1,6107 & $-300,80$ & $-289,56$ \\
\hline 8 & Gd-3-100 & 1,7055 & $-298,99$ & $-289,60$ \\
\hline \multicolumn{5}{|c|}{ Lanjutan Tabel 4.} \\
\hline No & Notasi & Safety factor & Settlement $(\mathrm{mm})$ & Tegangan tanah $\left(\mathrm{kN} / \mathrm{m}^{2}\right)$ \\
\hline 9 & Gd-3-200 & 1,7027 & $-298,84$ & $-289,62$ \\
\hline 10 & Gd-3-300 & 1,6961 & $-299,26$ & $-289,64$ \\
\hline 11 & Gd-3-400 & 1,6930 & $-299,31$ & $-289,61$ \\
\hline 12 & Gd-3-500 & 1,6898 & $-299,46$ & $-289,61$ \\
\hline 13 & Gd-4-100 & 1,7264 & $-298,06$ & $-289,66$ \\
\hline 14 & Gd-4-200 & 1,7213 & $-297,54$ & $-289,71$ \\
\hline 15 & Gd-4-300 & 1,7179 & $-298,18$ & $-289,68$ \\
\hline 16 & Gd-4-400 & 1,6986 & $-298,72$ & $-289,65$ \\
\hline 17 & Gd-4-500 & 1,6674 & $-302,55$ & $-289,80$ \\
\hline 18 & Gx-1 & 1,5520 & $-305,60$ & $-289,34$ \\
\hline 19 & Gx-2-100 & 1,5522 & $-303,74$ & $-289,39$ \\
\hline 20 & Gx-2-200 & 1,5573 & $-303,84$ & $-289,39$ \\
\hline 21 & Gx-2-300 & 1,5619 & $-304,05$ & $-289,39$ \\
\hline 22 & Gx-2-400 & 1,5670 & $-304,16$ & $-289,39$ \\
\hline 23 & Gx-2-500 & 1,5482 & $-304,34$ & $-289,38$ \\
\hline 24 & Gx-3-100 & 1,5536 & $-302,75$ & $-289,42$ \\
\hline 25 & Gx-3-200 & 1,5584 & $-302,99$ & $-289,42$ \\
\hline 26 & Gx-3-300 & 1,5663 & $-303,41$ & $-289,42$ \\
\hline 27 & Gx-3-400 & 1,5686 & $-303,62$ & $-289,40$ \\
\hline 28 & Gx-3-500 & 1,5376 & $-303,84$ & $-289,40$ \\
\hline 29 & Gx-4-100 & 1,5644 & $-302,15$ & $-289,44$ \\
\hline 30 & Gx-4-200 & 1,5657 & $-302,51$ & $-289,44$ \\
\hline 31 & Gx-4-300 & 1,5656 & $-303,11$ & $-289,44$ \\
\hline 32 & $G x-4-400$ & 1,5696 & $-303,56$ & $-289,41$ \\
\hline 33 & Gx-4-500 & 1,5379 & $-309,8$ & $-289,51$ \\
\hline
\end{tabular}

Keterangan,

Gd : geogrid

$G \times$ : geosintetik

Notasi Gd-2-100 menunjukkan bahwa kombinasi variasi yang digunakan adalah variasi geogrid berjumlah dualapis dengan jarak antar lapis sejauh $100 \mathrm{~mm}$. 
Tanda negatif pada Tabel 4 kolom settlement $(\mathrm{mm})$ menunjukkan bahwa penurunan terjadi semakin kebawah dari kedalaman $\pm 0 \mathrm{~m}$ menuju pada pusat bumi. Tanda negatif pada Tabel 4 kolom tegangan tanah $\left(\mathrm{kN} / \mathrm{m}^{2}\right) \mathrm{menun}-$ jukkan bahwa tegangan tanah bersifat saling menekan satu sama lain. Nilai tegangan tanah yang ditampilkan merupakan nilai tegangan efektif utama tanah maksimum yang terjadi pada pemodelan secara global.

Grafik hubungan antara hasil analisis dengan variabel penelitian ditampilkan pada Gambar 2 sampai dengan Gambar 7 dibawah ini,

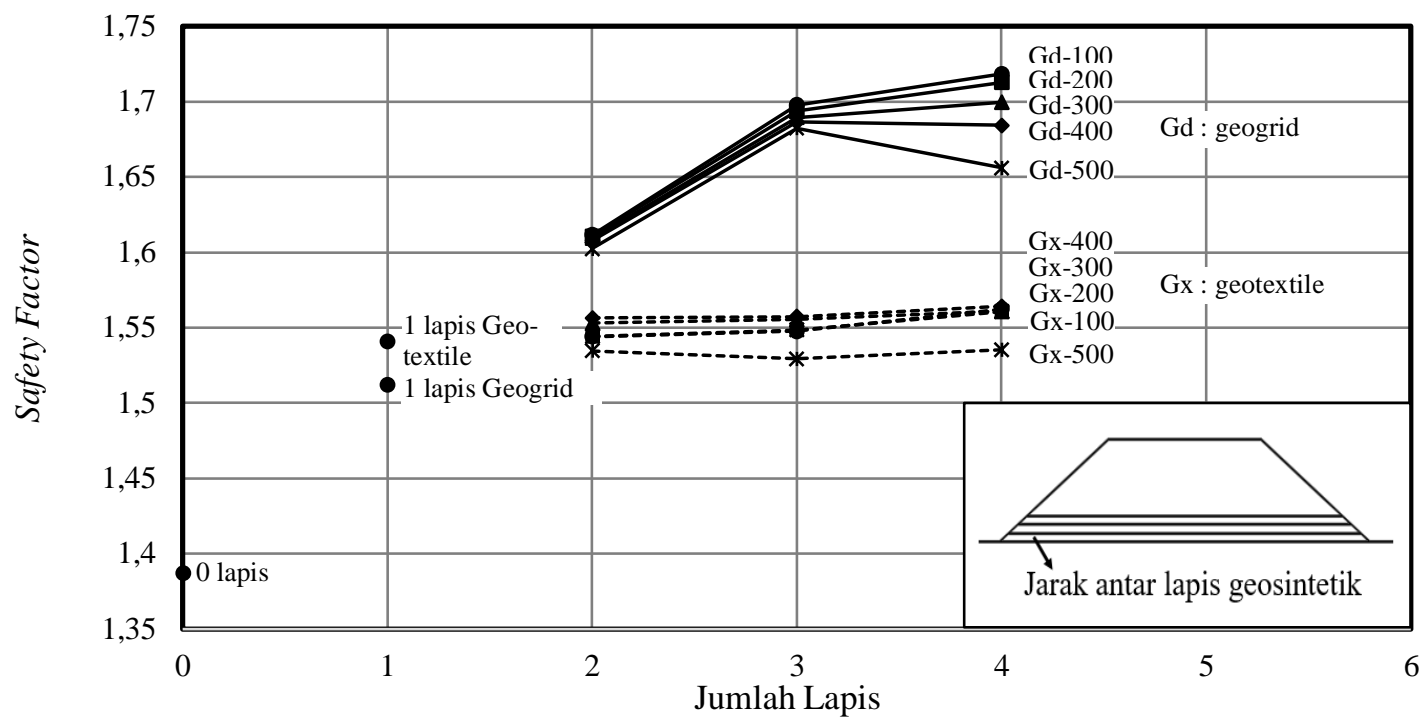

Gambar 2. Hubungan antara jumlah lapis geosintetik dengan nilai safety factor

Nilai safety factor yang ditunjukkan pada Gambar 2 terus meningkat seiring dengan penggunaan jumlah lapis geosintetik yang terus bertambah. Jumlah lapis geosintetik yang terus bertambah menyebabkan semakin besarnya nilai kapasitas daya dukung ultimit dari timbunan tersebut. Peningkatan nilai kapasitas daya dukung ultimit ini disebabkan karena nilai $E A$ dan nilai tegangan geser yang dimiliki oleh masaing-masing lapisan geosintetik yang digunakan.

Geosintetik yang dipasang mampu mendorong bidang runtuh bergerak keluar, sehingga akan meningkatkan nilai tahanan geser pada tanah (Hardiyatmo, 2008). Tahanan geser tanah yang meningkat menyebabkan meningkatnya kapasitas dukung ultimit tanah, dan kapasitas dukung ultimit yang meningkat mampu meningkatkan nilai safety factor.

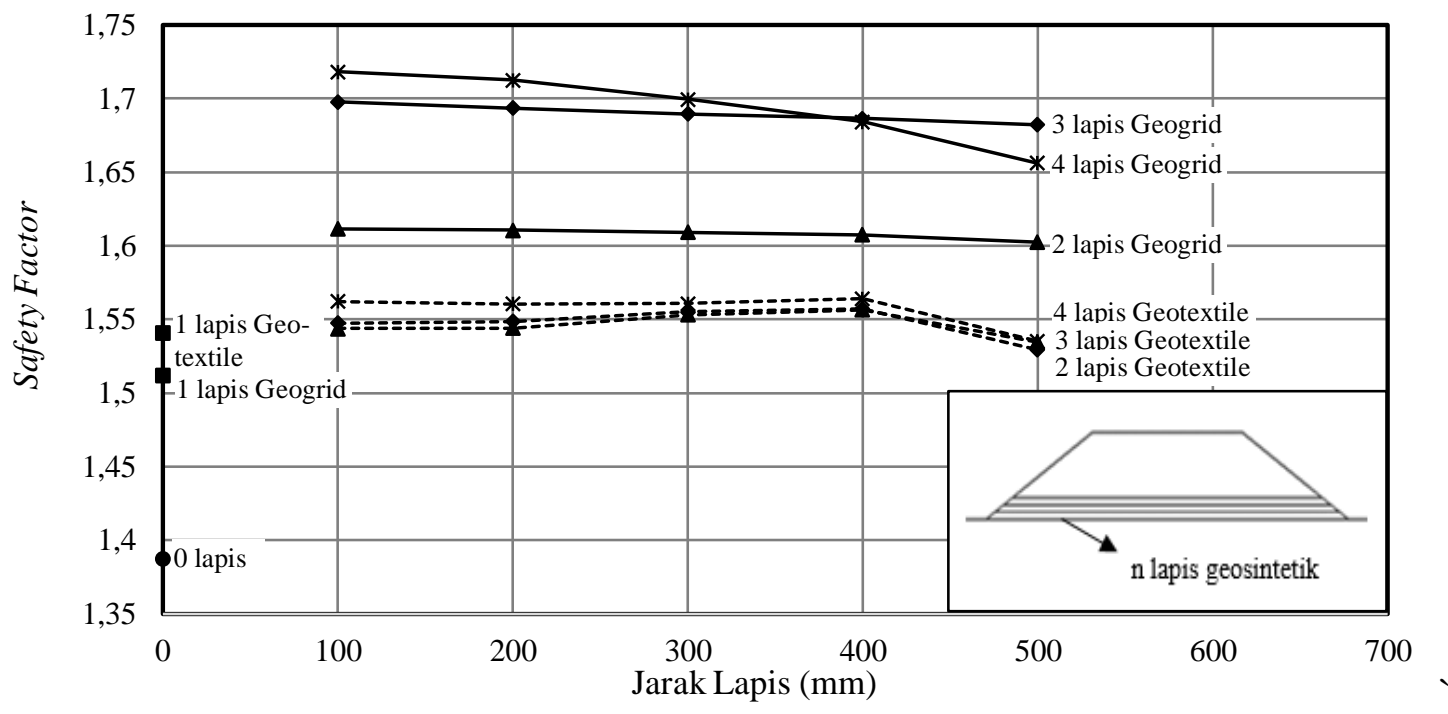

Gambar 3. Hubungan antara jarak antar lapis geosintetik dengan nilai safety factor 
Semakin besar jarak antar lapis geosintetik yang digunakan maka semakin turun nilai safety factor tanah, meskipun penurunan yang terjadi tidak begitu signifikan pada penggunaan satu lapis sampai dengan tiga lapis geosintetik sesuai dengan Gambar 3. Jarak antar lapis geosintetik yang semakin besar menyebabkan masing-masing lapis geosintetik memikul berat tanah yang semakin besar pula, hal ini dapat menurunkan nilai safety factor karena beban yang dipikul masing-masing lapis bertambah banyak.

Gambar 2 dan Gambar 3 menunjukkan bahwa penggunaan lapis geogrid tipe GX(40/40) lebih efisien dan optimum digunakan pada timbunan diatas tanah lunak karena mampu meningkatkan nilai safety factor yang lebih signifikan dibanding penggunaan lapis geotextile tipe GRX50. Penggunaan variasi lapis paling optimum adalah variasi 4 lapis geogrid jarak antar lapis $100 \mathrm{~mm}$ dengan nilai safety factor sebesar 1,7264 atau mengalami kenaikan dari safety factor tanah tanpa perkuatan sebesar $23,79 \%$.

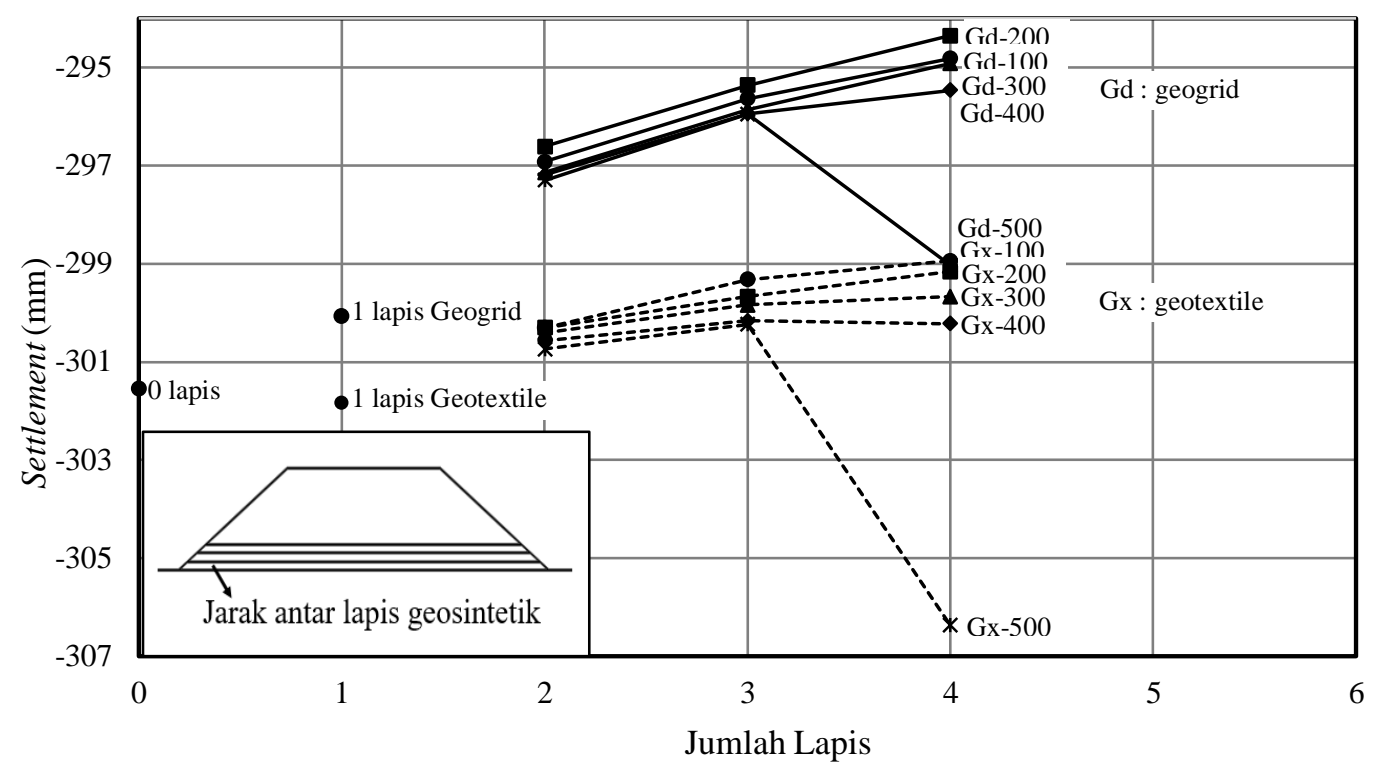

Gambar 4. Hubungan antara jumlah lapis geosintetik dengan nilai settlement

Nilai settlement terus berkurang selaras dengan penambahan jumlah geosintetik yang digunakan, kecuali pada penggunaan variasi 4 lapis geosintetik dengan jarak $500 \mathrm{~mm}$ antar lapis dan selapis geotextile sesuai seperti yang ditunjukkan pada Gambar 4. Hal ini menunjukkan bahwa penambahan jumlah lapis geosintetik mampu mengurangi settlement pada timbunan di atas tanah lunak, tetapi memiliki variasi optimum penggunaan.

Geosintetik memiliki parameter kekakuan aksial (EA) pada masing-masing lapisnya. Parameter kekakuan aksial menyebakan lapis geosintetik mampu menahan beban aksial mengurangi adanya settlement yang diakibatkan oleh beban aksial tersebut sesuai dengan batas maksimum yang dimiliki oleh lapis geosintetik tersebut. Bertambahnya jumlah geosintetik mengakibatkan bertambahnya pula nilai parameter kekakuan pada suatu sistem timbunan tersebut, sehingga settlement yang terjadi dapat terus berkurang. 


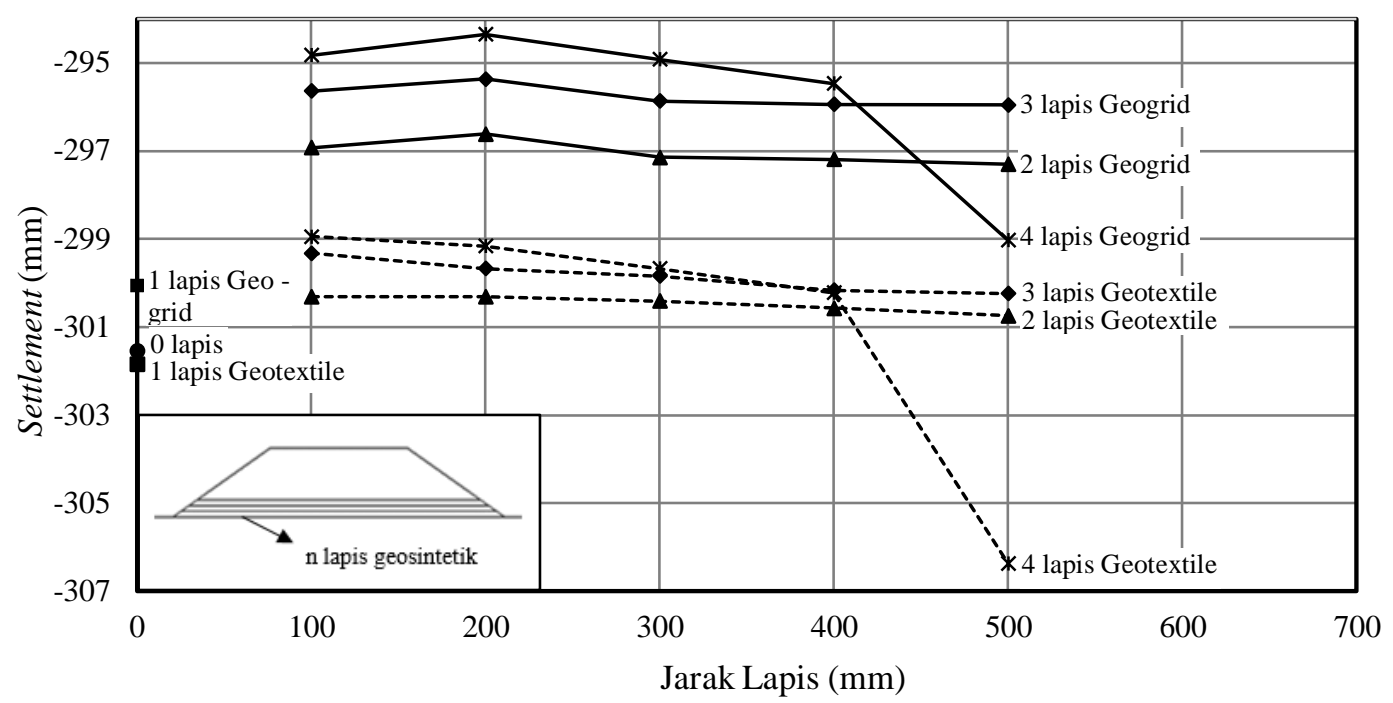

Gambar 5. Hubungan antara jarak antar lapis geosintetik dengan nilai settlement

Penggunaan variasi jarak antar lapis mengurani nilai settlement hanya sampai dengan jarak antar lapis $200 \mathrm{~mm}$ seperti yang ditunjukkan pada Gambar 5. Bertambahnya nilai settlement yang selaras dengan penambahan jarak antar lapis geosintetik setelah $200 \mathrm{~mm}$ menunjukkan bahwa parameter kekauan aksial $(E A)$ hanya bekerja optimum sampai dengan jarak $200 \mathrm{~mm}$ antar lapisnya. Penambahan jarak antar lapis menyebabkan parameter kekakuan aksial tidak bekerja secara optimal, karena penambahan beban yang harus ditanggung untuk tiap lapisnya.

Penggunaan variasi geogrid tipe GX(40/40) lebih berpengaruh terdadap nilai settlement dibanding dengan penggunaan variasi geotextile tipe GRX50 sebagaimana ditunjukkan pada Gambar 4 dan Gambar 5. Variasi yang memberi pengaruh terbesar yaitu variasi 4 lapis geogrid jarak antar lapis $200 \mathrm{~mm}$ dengan pengurangan sebesar 2,60\% dari settlement tanah tanpa perkuatan.

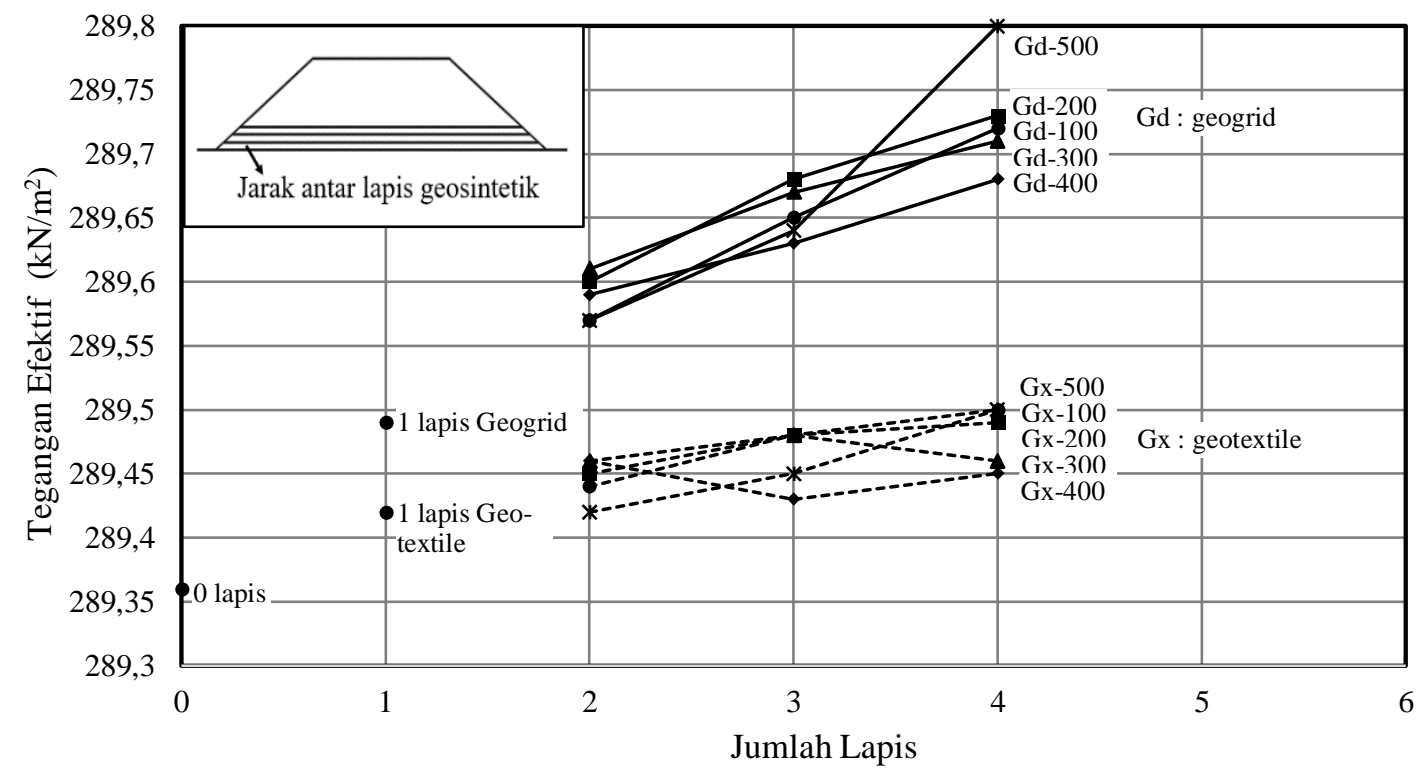

Gambar 6. Hubungan antara jumlah lapis geosintetik dengan nilai tegangan tanah

Gambar 6 menunjukkan bahwa penambahan penggunaan lapis geosintetik meningkatkan nilai tegangan tanah timbunan di atas tanah lunak. Nilai tegangan tanah meningkat selaras dengan penambambahan beban yang dibebankan pada suatu tanah, sehingga dengan meningkatnya nilai tegangan tanah pada penggunaan lapis geosintetik menunjukkan bahwa beban yang diterima oleh tanah semakin meningkat pula, meskipun dalam kasus ini peningkatan yang terjadi tidak signifikan. Peningkatan beban ini diindikasikan karena berat sendiri lapis geosintetik yang digunakan sebagai perkuatan. 


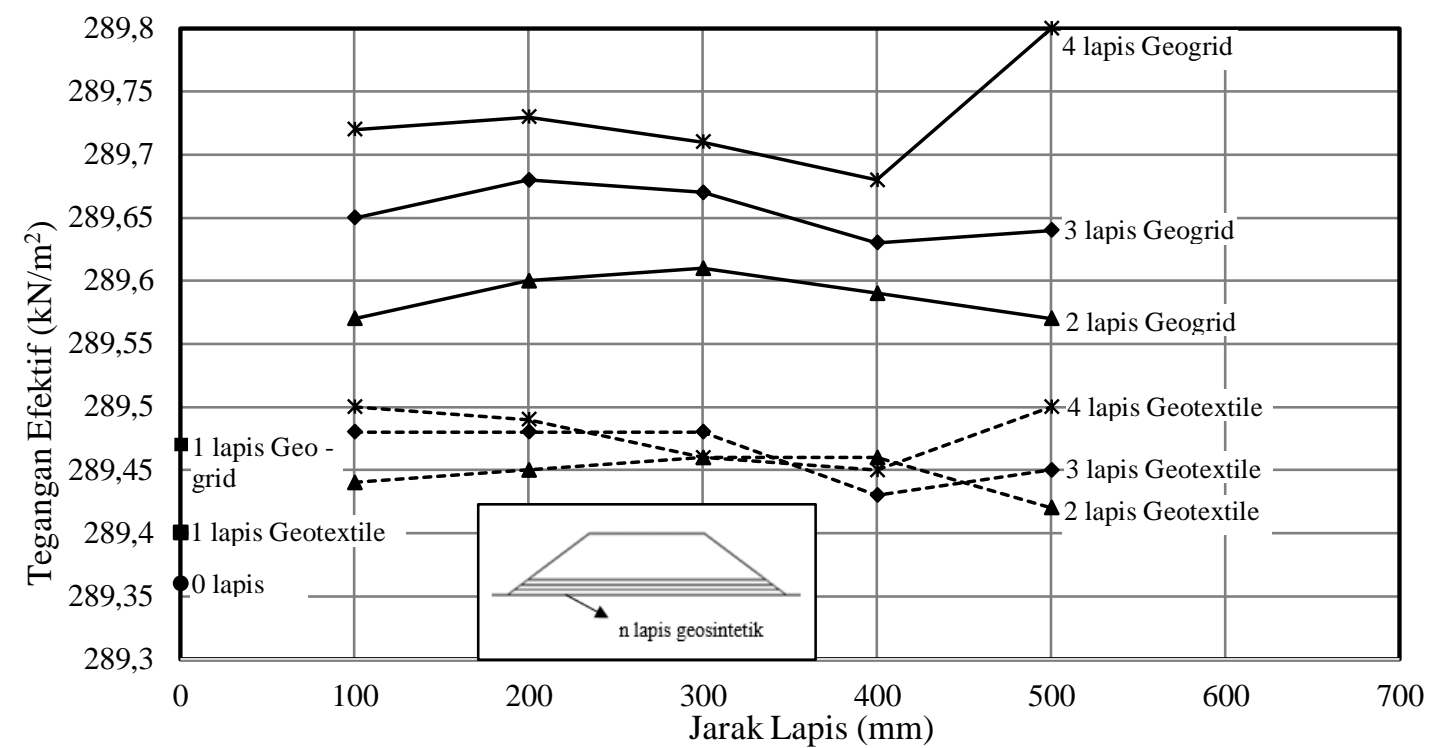

Gambar 7. Hubungan antara jarak antar lapis geosintetik dengan nilai tegangan tanah

Fluktuasi nilai tegangan tanah yang diakibatkan dari penggunaan variasi jarak antar lapis geosintetik ditunjukkan pada Gambar 7. Fluktuasi perubahan nilai tegangan tanah yang terjadi menunjukkan bahwa pengaplikasian jarak antar lapis geosintetik memberikan pengaruh terhadap beban yang diterima oleh tanah akibat beban yang dikenakan pada pemodelan dalam penelitian ini, meskipun pengaruh yang diberikan tidak signifikan. Hubungan antara penambahan jarak antar lapis geosintetik dengan perubahan nilai tegangan efektif utama tanah dalam kasus ini tidak dapat disimpulkan.

Penggunaan variasi geogrid tipe GX(40/40) lebih berpengaruh terhadap nilai tegangan efektif utama tanah dibanding dengan penggunaan variasi geotextile tipe GRX50 yang ditunjukkan pada Gambar 6 dan Gambar 7. Penggunaan variasi yang paling besar pengaruhnya adalah variasi empat lapis geogrid dengan jarak $500 \mathrm{~mm}$ dengan kenaikan nilai tegangan efektif utama sebesar $0,17 \%$ dari tegangan tanah tanpa perkuatan.

Penggunaan lapis geosintetik secara teori akan menyebabkan distribusi beban yang merata pada setiap lapisan permukaan tanah yang dihamparkan perkuatan geosintetik diatasnya. Beban yang merata pada setiap permukaan tanah ini menyebabkan tegangan tanah yang dihasilkan juga lebih merata pada setiap titiknya (Pedoman Konstruksi dan bangunan No. 003/BM/2009). Fungsi lapis geosintetik terhadap tegangan tanah pada timbunan di atas tanah lunak adalah untuk mendistribusikan tegangan tanah agar lebih merata pada setiap titik, sehingga mengurangi adanya resiko keruntuhan lokal pada suatu titik pada timbunan tersebut.

\section{SIMPULAN}

Kesimpulan dari penelitian ini adalah bahwa penggunaan variasi lapis geosintetik yang paling optimum dapat meningkatkan nilai safety factor sebesar 33,79\%, menurunkan settlement sebesar 2,60\%, dan meningkatkan tekanan tanah sebesar $0,17 \%$.

\section{REKOMENDASI}

Penelitian mengenai geosintetik ini dapat dikembangkan dengan meninjau analisis konsolidasi jangka panjang, beban gempa, beban dinamis, dan pengaruh muka air tanah.

\section{UCAPAN TERIMAKASIH}

Kami mengucapkan terimakasih kepada PT. Tetrasa GEOSININDO atas data-data yang telah diberikan kepada kami, sehingga penelitian ini dapat selesai dengan lancar.

\section{REFERENSI}

Hardiyatmo, H. C, 2008, “Geosintetik untuk Rekayasa Jalan Raya”, Cetakan pertama, Yogyakarta: Gadjah Mada University Press. 
Siska, dkk, 2016, "Karakterisasi Sifat Fisis dan Mekanis Tanah Lunak di Gedebage”, Bandung: Jurnal terbuka, Vol. 2 No. 4.

Tay, dkk, 2014, “Analisa Perkuatan Geotekstil pada Timbunan Konstruksi Jalan dengan Plaxis 2D”, Surabaya: Jurnal dimensi pratama teknik sipil, Vol. 3 No. 2.

Zaika, dkk, 2010, "Penggunaan Geotextil sebagai Alternatif Perbaikan Tanah Terhadap Penurunan Pondasi Dangkal", Malang: Jurnal terbuka, Vol. 2 No. 4. 